\title{
Albendazole therapy reduces serum zinc in elementary school children with Ascaris lumbricoides infections
}

\author{
Ria Buana*, Jane Florida Kalumpiu**, Yenny Djuardi***, and Taniawati Supali***
}

\section{ABSTRACT}

*Department of Parasitology, Faculty of Medicine,

Tarumanagara University, Jakarta

**Department of Parasitology,

Faculty of Medicine,

Trisakti University, Jakarta

***Department of Parasitology,

Faculty of Medicine,

University of Indonesia, Jakarta

\section{Correspondence:}

dr. Ria Buana, M.Biomed

Department of Parasitology,

Faculty of Medicine,

Tarumanagara University

Jl. S. Parman No. 1

Jakarta Barat 11440

+62215671781, +628129657508

riabuana@ymail.com

Univ Med 2016;35:206-12

DOI: 10.18051/UnivMed.2016.v35.206-212 pISSN: 1907-3062 / eISSN: 2407-2230

This open access article is distributed under a Creative Commons Attribution-Non Commercial-Share Alike 4.0 International License

\section{BACKGROUND}

Soil-transmitted helminth (STH) infection can cause malnutrition and vice versa, and decrease serum zinc concentrations. No previous studies were found on the effect of STH treatment on serum zinc concentrations in elementary school children. The objective of this study was to evalaute the effect of STH treatment on serum zinc concentration in elementary school children in Jakarta.

\section{METHODS}

A pre-experimental study (one group pre and post) was conducted on $3^{\text {rd }}$ $-5^{\text {th }}$ grade students in one elementary school in North Jakarta. FLOTAC examination was used to determine infection status and STH intensity, while serum zinc concentrations were measured by atomic absorption spectrometry. All children were given albendazole $400 \mathrm{mg}$ for three consecutive days. Stool and blood samples were collected before and three weeks after treatment with albendazole. A paired t test was used to analyze the data.

\section{RESULTS}

The STH prevalence was 63.4\%; these were mainly Ascaris lumbricoides and Trichuris trichiura infections. Before treatment, children infected with A.lumbricoides and T.trichiura had significantly higher serum zinc concentrations $(\mathrm{p}=0.028 ; \mathrm{p}=0.014)$. After treatment, children with A.lumbricoides had significantly lower serum zinc concentrations ( $\mathrm{p}=0.039$ ), while children with T.trichiura had slightly lower serum zinc concentrations $(\mathrm{p}=0.659)$ than before treatment.

\section{CONCLUSIONS}

Albendazole treatment produces lower serum zinc concentration in elementary school children with A.lumbricoides infections. A profound understanding of the interaction between helminth infections and zinc may assist in guiding integrated and sustainable intervention strategies among affected children throughout the world.

Keywords: Serum zinc, albendazole, STH, children 


\section{INTRODUCTION}

Soil-transmitted helminth (STH) infection is the most frequent helminth infection in humans, particularly inhabitants of tropical or subtropical countries. The WHO estimates that more than 2 million people are infected with STH. Helminth infection occurs more frequently in school-age children. ${ }^{(1)}$ Soil humidity, climate, environmental sanitation, lack of sources of clean water and habits of the inhabitants are factors that influence the high prevalence of STH infection. ${ }^{(1,2)}$ In 2006, 195 million persons in Indonesia resided in endemic areas and 50 million among them were school-age children. ${ }^{(3)}$ In Jakarta, the prevalence of STH infection is still high, particularly in crowded slum areas. ${ }^{(4)}$ Helminths can evade the host immune system, resulting in chronic infection. Helminth infection stimulates the production of the cytokines interleukin-4 (IL-4), IL-5, IL-10, IL-13 and immunoglobulin $\mathrm{E}$ (IgE). ${ }^{(5)}$ The diagnosis of STH infection is established by finding helminth eggs in the stool by microscopy with the FLOTAC technique, because of its higher sensitivity. ${ }^{(6)}$ Albendazole is an anthelminthic that effectively manages STH infection with substantially high cure rates for Ascaris lumbricoides and hookworm infections, but is less effective in Trichuris trichiura infections. ${ }^{(7)}$

Helminth infections and micronutrient deficiencies are highly prevalent in developing countries and often occur in the same individuals. ${ }^{(8)}$ Zinc is an essential element that is required for cell growth, development and differentiation, and plays a role in the synthesis of proteins, enzymes and transcription factors. Zinc deficiency can occur as a result of malabsorption syndrome in chronic gastrointestinal disturbances. ${ }^{(9)}$ Zinc cannot be stored in the body and is excreted by the kidneys, the skin and the intestine, while its concentration is maintained through tissue catabolism and bone resorption. ${ }^{(10)}$ Helminths require zinc for their biology, such as the production of the zincdependent metalloproteinases, invasion of host tissues, digestion of food, development of their eggs, and for neutralizing the host immune system. ${ }^{(11)}$ Zinc deficiency in children can cause abnormalities of growth and cognitive development, and render them more susceptible to disease. ${ }^{(12)}$ A number of previous studies found that serum zinc in children with helminth infections did not undergo significant changes. ${ }^{(13,14)}$

Since STH infections still occur frequently in Indonesia, particularly in communities of low economic status with poor sanitation, and may have a negative impact on serum zinc concentration that can affect immunity, growth and cognitive function in children, it was considered necessary to carry out a study to determine serum zinc concentration in school-age children before and after treatment for STH infection.

\section{METHODS}

\section{Study design}

This was a pre-experimental study of one group pre- and post-test design that was conducted at Kalibaru state elementary school 07 (SDN 07), Cilincing, North Jakarta from May to October 2014.

\section{Study subjects}

The population comprised students of elementary school grades 3-5, and the inclusion criteria were: not consuming anthelminthic drugs in the last 6 months, healthy and without fever, agreeing to participate in this study with written informed consent, with their parents allowing them to participate in this study after signing informed consent. The exclusion criterion was refusal to consume albendazole. The estimated sample size was calculated using the formula for hypothesis testing of two paired populations by taking power of $80 \%$ and significance level of $5 \%$, resulting in the required sample size of 32 children. In anticipation of drop outs (10\%), the required sample size was taken as 35 children. ${ }^{(15)}$ Based on a preliminary survey performed in the SDN 07 Kalibaru complex, yielding an STH infection 
prevalence of $30 \%$, the required sample was 117 children for screening.

\section{Parasitological examination and treatment}

The stool samples were examined in August 2014 in the Parasitology laboratory, Faculty of Medicine, University of Indonesia, while the blood examination was performed in September 2014 in the SEAMEO RECFON laboratory, Faculty of Medicine, University of Indonesia. The stool samples were examined by the FLOTAC method, which is based on a centrifugal flotation technique. The weight of the stool samples was 1 gram per sample. The apparatus used in the FLOTAC technique was a cylinder made of polycarbonate amorphous thermoplastic and consisting of 3 physical components (core components), i.e. base, translation disc and reading disc, in which two flotation chambers are located for holding the samples, each chamber having a volume of $5 \mathrm{ml}$ (total volume $=10 \mathrm{~mL}$ ). There are five accessories, i.e. screw, key, bottom, centrifuge adapter and microscope adapter, which together with the core components make up the assembled apparatus for use in the centrifugation process and at microscopic examination. The present study used the dual technique with two types of FLOTAC solution, namely $\mathrm{NaCl}$ and sucrose. ${ }^{(16)}$

Infection intensity was determined by counting the number of helminth eggs in 1 gram of feces (Table 1). ${ }^{(17)}$ Albendazole $400 \mathrm{mg}$ chewable tablets were administered orally and ingested on the spot by the respondents as witnessed by the investigators assisted by the form teacher.

\section{Serum zinc}

Serum zinc concentrations were determined in the SEAMEO RECFON laboratory, Faculty of Medicine, University of Indonesia, using atomic absorption spectrometry (AAS) to determine the quantities of chemical substances by measuring the radiation absorbed by the chemical substance in question. This is accomplished by reading the spectrum produced by the sample upon stimulation by radiation. The atoms will absorb ultraviolet or other rays and convert them into certain levels of energy. This method measures the amount of energy produced in the form of photons absorbed by the sample. A detector is used to measure the wave length of the transmitted radiation, while a processor integrates the absorbed wave length into the result. This method is based on the Beer-Lambert law. ${ }^{(18)}$

\section{Data analysis}

The difference of serum zinc concentration before and after treatment was analyzed using the paired $t$ test. Statistical significance was defined as a $\mathrm{p}$ value below 0.05 ,

\section{Ethical clearance}

This study was approved by the Ethics Commission, Faculty of Medicine, University of Indonesia and Cipto Mangunkusumo Hospital under No. 500/H2.F1/ETIK/2014.

\section{RESULTS}

A total of 127 children agreed to participate in this study, but only 115 stool samples and 88 blood samples were successfully collected. After treatment with albendazole $400 \mathrm{mg}$ for 3 consecutive days, stool and blood samples were again collected, resulting in 82 stool samples and 87 blood samples. A total of 78 paired blood samples (before and after treatment) were successfully collected (Figure 1).

The majority of respondents were 10 years of age, of female gender, while their parents had low educational level (junior high school graduates), and most were employed as laborers

Table 1. Infection intensity based on number of eggs per gram (EPG). ${ }^{(17)}$

\begin{tabular}{cccc}
\hline Helminth species & Mild infection & Moderate infection & Severe infection \\
\hline A lombricaides & $1-4.999$ & $5.000-49.999$ & $\geq 50.000$ \\
T. trichiva & $1-999$ & $1.000-9.999$ & $\geq 10.000$ \\
Hookworm & $1-1.999$ & $2.000-3.999$ & $\geq 4.000$ \\
\hline
\end{tabular}




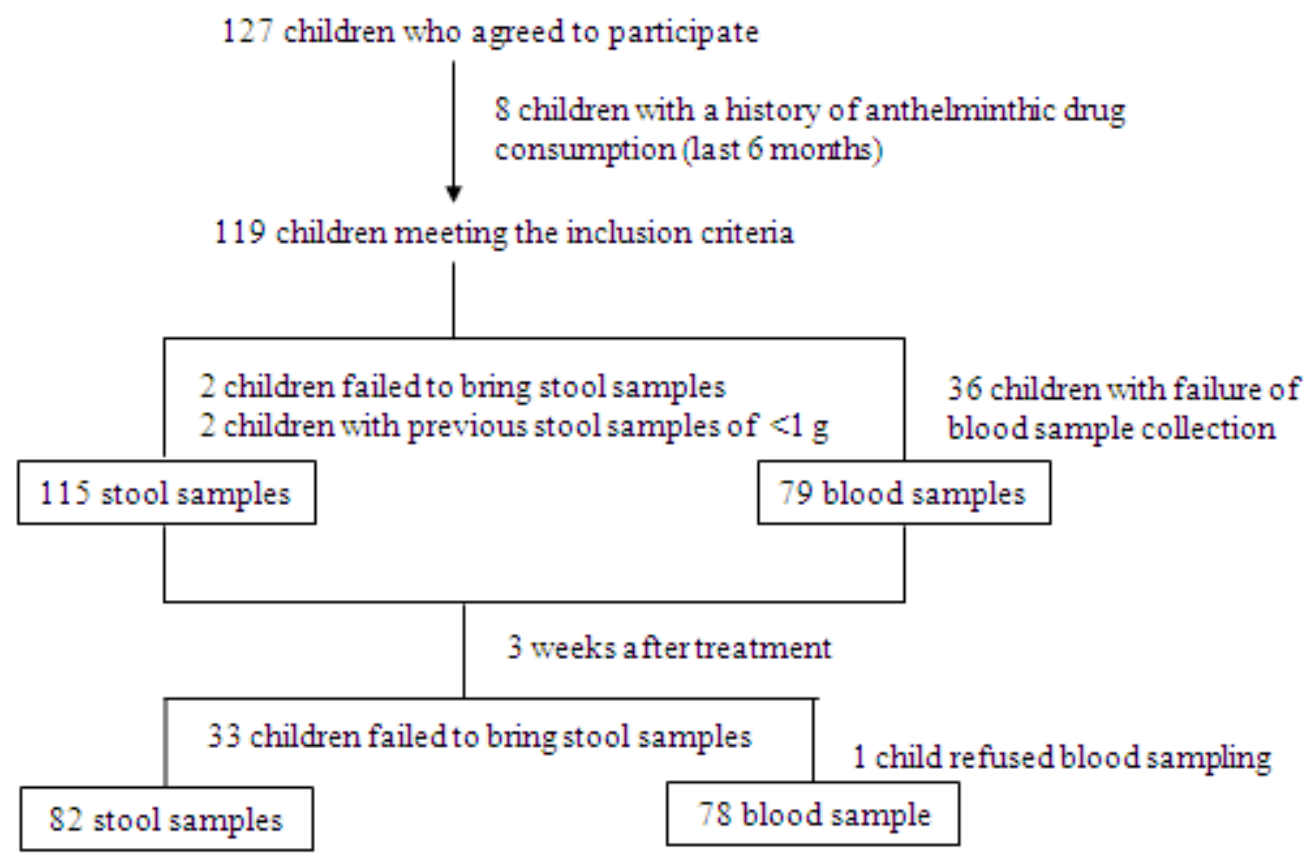

(Table 2). Upon examination of the 115 stool samples before treatment, $72(63.4 \%)$ children were found to be infected with STH, consisting of $30(26.0 \%)$ children with A.lumbricoides, 20 (17.4\%) children with T.trichiura, and 23 $(20.0 \%)$ children with mixed infection (Table 2$)$. In the 82 samples after treatment, a decrease in the prevalence of STH infection was found, in which $14(17.1 \%)$ children still had helminth infection, consisting of 3 (3.6\%) children with A.lumbricoides, 10 (12.2\%) children with $T$. trichiura, and $1(1.2 \%)$ child with mixed infection (A.lumbricoides and T.trichiura). Before treatment, STH infection was more prevalent in female children than in male children, but after treatment the prevalence of STH infection in children of both genders was reduced.

Before treatment, the majority of children with A.lumbricoides infection had mild infection (1-4999 EPG), while the remaining children had moderate infection (5.000 - 49.000 EPG). In the mixed infections, the intensity of A.lumbricoides infection was mild to moderate, whereas T.trichiura infection was of mild intensity only (1-999 EPG). After treatment, the prevalences of STH infection, both moderate and mild, were substantially reduced in each type of STH infection (data not shown).
Table 2. Distribution of sosciodemographic characteristics, nutritional and STH infection status $(\mathrm{n}=115)$

\begin{tabular}{|c|c|}
\hline Characte ristic & n $(\%)$ \\
\hline \multicolumn{2}{|l|}{ Age } \\
\hline 9 years & $28(24.3)$ \\
\hline 10 years & $62(53.9)$ \\
\hline 11 years & $25(21.7)$ \\
\hline \multicolumn{2}{|l|}{ Gender } \\
\hline Male & $52(45.2)$ \\
\hline Female & $63(54.8)$ \\
\hline \multicolumn{2}{|l|}{ Parental education } \\
\hline El ementary school & $29(25.2)$ \\
\hline Juni or high school & $48(41.7)$ \\
\hline Senior high school & $36(31.3)$ \\
\hline Tertiary education & $2(1.7)$ \\
\hline \multicolumn{2}{|l|}{ Parental occupation } \\
\hline Labor er & $88(76.5)$ \\
\hline Fisher & $8(7.0)$ \\
\hline Tail $\boldsymbol{\alpha}$ & $1(0.9)$ \\
\hline Em ployee s & $4(3.5)$ \\
\hline Entrepreneux & $11(9.6)$ \\
\hline Driver & $2(1.7)$ \\
\hline Civil servants & $1(0.9)$ \\
\hline \multicolumn{2}{|l|}{ Nutritional status } \\
\hline Underw eight. & $6(5.8)$ \\
\hline Normal & $82(79.6)$ \\
\hline Overweight & $9(8.7)$ \\
\hline Obesity & $6(5.8)$ \\
\hline \multicolumn{2}{|l|}{ STH infection status } \\
\hline Negative & $43(37.4)$ \\
\hline AL infection* & $30(26.0)$ \\
\hline TT infection $*$ & $20(17.4)$ \\
\hline Mixed infection & $23(20.0)$ \\
\hline
\end{tabular}

*AL : Ascaris lumbricoides; TT : Trichuris trichiura 
Table 3. Relationship between STH infection and serum zinc concentration before and after treatment

\begin{tabular}{lcccc}
\hline \multirow{2}{*}{ STH infection } & \multicolumn{3}{c}{ Sermm xinc (umolL) } \\
\cline { 2 - 4 } & $\begin{array}{c}\text { Before tre atm ent } \\
(\mathbf{n}=\mathbf{7 9})\end{array}$ & $\begin{array}{c}\text { After treatment } \\
(\mathbf{n}=\mathbf{7 8})\end{array}$ & Difference ** & P \\
\hline Infection status & $12.17 \pm 2.16$ & $12.02 \pm 1.68$ & $-0.15 \pm 1.95$ & 0583 \\
$\quad$ Positive & $11.42 \pm 2.15$ & $11.06 \pm 1.90$ & $-0.36 \pm 1.86$ & 0302 \\
Negative & $12.33 \pm 1.81$ & $11.40 \pm 1.45$ & $-0.93 \pm 1.93$ & $0.039 *$ \\
Alumbricoides & $12.99 \pm 2.51$ & $12.79 \pm 1.68$ & $-0.19 \pm 1.44$ & 0.659 \\
T.trichiura & $11.41 \pm 2.21$ & $12.29 \pm 1.76$ & $0.88 \pm 1.91$ & 0.082 \\
Mixed infection & $11.42 \pm 2.15$ & $11.06 \pm 1.90$ & $-0.36 \pm 1.86$ & 0302 \\
Negative & & & \\
\hline
\end{tabular}

aPaired t-test; * Significant; ** Mean zinc concentration after treatment subtracted by mean zinc concentration before treatment

After treatment, mean serum zinc concentration decreased by $0.15 \pm 1.95 \mu \mathrm{mol} / \mathrm{L}$ in children with STH infection and by $0.36 \pm 1.86$ $\mu \mathrm{mol} / \mathrm{L}$ in children without STH infection. Using the paired t-test, no significant differences were found in mean serum zinc concentration before and after treatment, both in children with STH infection $(\mathrm{p}=0.583)$ and in those without STH infection $(p=0.302)$ (Table 3$)$. To test for differences in mean serum zinc concentration for each type of helminth infection before and after treatment, an analysis was made with the paired t-test, which found a significant decrease in mean serum zinc concentration after treatment in children with A.lumbricoides infection ( $\mathrm{p}=0.039)$, but no significant decrease in children with T.trichiura infection and in those without infection $(p=0.659)$. On the other hand, in children with mixed infection a nonsignificant increase in mean serum zinc concentration was found after treatment $(\mathrm{p}=0.082)($ Table 3$)$.

\section{DISCUSSION}

Before treatment, serum zinc concentration in children with STH infection was higher than in children without infection, but there were no significant differences. This finding agrees with that of a study conducted by Osei et al. ${ }^{(19)}$ in elementary school children in India, in that helminth infection of the intestine does not influence zinc concentration. However, this study did not differentiate between helminth species. In contrast, in our study serum zinc concentration was analyzed in relation to the infecting helminth species. Our results differ from those of a study carried out by Kongsbak et al. ${ }^{(20)}$ in Bangladesh, where it was found that children with STH infection had significantly lower serum zinc concentrations than those without infection. There are several possible mechanisms that may clarify the differences between our study results and those of the aforementioned study. Firstly, these differences may be caused by differing tissue catabolism as a result of the helminth infection, thus increasing the serum zinc concentration in our study. Secondly, STH infection may cause abnormal absorption of zinc, resulting in compensatory changes in the form of increased synthesis of zinc transporters, such as ZIP4 that transports zinc from the intestinal lumen into enterocytes and ZnT1 that functions to transport zinc out of the enterocytes into the blood, leading to increases in serum zinc concentrations. ${ }^{(21)}$

After treatment, serum zinc concentration was significantly decreased in children with A.lumbricoides infection, but not significantly in children with T.trichiura infection. Furthermore, in children with mixed infection or without infection, there was a nonsignificant increase in serum zinc concentration. These results may be due to the fact that the small intestine is undergoing mucosal repair after helminth infection, thus causing a decrease in zinc transporter molecules in the enterocytes (ZIP4 and $\mathrm{ZnT} 1),{ }^{(22)}$ and also decreasing the amount of zinc 
that is transported into the blood. In addition, the body may be attempting to remove the helminths that had died after treatment, through the cytokines IL-4, IL-5, IL-9, IL-10, and IL-13, that require more zinc for their production and activity. ${ }^{(23)}$ Another factor may be the possibility of other infections that were not investigated in this study, that can cause decreased zinc concentration, such as infection with the intestinal protozoa Giardia lamblia. ${ }^{24.25)}$

The present study has several limitations, the first being that no investigation was done on possible infection with intestinal protozoa, such as G.lamblia. The second limitation is the possibility that several blood samples underwent hemolysis, thus increasing serum zinc concentration. Further studies are required, with longer surveillance periods and higher infection intensities, including the possibility of other infections that were not investigated in this study apart from STH infection.

\section{CONCLUSIONS}

Treatment with the maximal dose of albendazole causes decreased serum zinc in children with STH infection. A profound understanding of the interaction between helminth infections and zinc may assist in guiding integrated and sustainable intervention strategies among affected children throughout the world.

\section{CONFLICT OF INTEREST}

The authors declare that there is no conflict of interest in this study.

\section{ACKNOWLEDGMENT}

The investigators are greatly indebted to all parties without whose participation this study would not have been conducted.

\section{REFERENCES}

1. World Health Organization. Eliminating soil transmitted helminthiases as a public health problem in children. Progress report 2001-2010 and strategic plan 2011-2020. Geneva: World Health Organization; 2012.

2. Brooker S, Clements AC, Bundy DA. Global epidemiology, ecology and control of soiltransmitted helminth infections. Adv Parasitol 2006;62:221-61.

3. Tan M, Kusriastuti R, Savioli L, et al. Indonesia: an emerging market economy beset by neglected tropical diseases (NTDs). PLoS Negl Trop Dis 2014;8:e2449.

4. Mardiana, Djarismawati. Prevalensi cacing usus pada murid Sekolah Dasar wajib belajar pelayanan gerakan terpadu pengentasan kemiskinan di wilayah kumuh di daerah DKI Jakarta. Jurnal Ekologi Kesehatan 2008;72:76974.

5. Bethony J, Brooker S, Albonico M, et al. Soiltransmitted helminth infections: ascariasis, trichuriasis, and hookworm. The Lancet 2006;367:1521-32.

6. Utzinger J, Rinaldi L, Lohourignon LK, et al. FLOTAC: a new sensitive technique for the diagnosis of hookworm infections in humans. Trans Roy Soc Trop Med 2007;102:84-90.

7. Samuel A, Degarege AB, Erko B. Efficacy and side effects of albendazole currently in use against Ascaris, Trichuris and hookworm among school children in Wondo Genet, Southern Ethiopia. Parasitol Int 2014;63:450-5.

8. Hurst RJ, Else KJ. Retinoic acid signalling in gastrointestinal parasite infections: lessons from mouse models. Parasite Immunol 2012;34:3519.

9. John E, Laskow TC, Buchser WJ, et al. Zinc in innate and adaptive tumor immunity. J Transl Med 2010;8:118.

10. De Benoist B, Darnton-Hill I, Davidsson L, et al. Conclusions of the joint WHO/UNICEF/ IAEA/IZiNCG interagency meeting on zinc status indicators. Food Nutr Bull 2007;28 Suppl 3:S480-4.

11. Dzik JM. Molecules released by helminth parasites involved in host colonization. Acta Biochim Pol 2006;53:33-64.

12. Cole CR, Grant FK, Ellis ED, et al. Zinc and iron deficiency and their interrelations in lowincome African American and Hispanic children in Atlanta. Am J Clin Nutr 2010: 91:1027-34.

13. Osei A, Houser R, Bulusu S, et al. Nutritional status of primary schoolchildren in Garhwali Himalayan villages of India. Food Nutr Bull 2010;31:221-33.

14. Orden AB, Apezteguía MC, Ciarmela ML, et al. Nutritional status in parasitized and nonparasitized children from two districts of 
Buenos Aires, Argentina. Am J Hum Biol 2014; 26:73-9.

15. Madiyono B, Moeslichan S, Sastroasmoro S, et al. Perkiraan besar sampel. In: Sastroasmoro S, Ismail S (editors). Dasar-dasar metodologi penelitian klinis, $4^{\text {th }}$ ed. Sagung Seto: Jakarta; 2011.p.348-82.

16. Cringoli G, Rinaldi L, Maurelli MP, et al. FLOTAC: new multivalent techniques for qualitative and quantitative copromicroscopic diagnosis of parasites in animals and humans. Nat Protoc 2010;5:503-5.

17. World Health Organization. Prevention and control of schistosomiasis and soil-transmitted helminthiasis, WHO Technical Report Series, No. 912. Geneva: WHO;2002.

18. García R, Báez AP. Atomic absorption spectrometry (AAS). In: Farrukh AM, editor. Atomic absorption spectroscopy. Croatia: Intech Open;2012.

19. Osei A, Houser R, Bulusu S, et al. Nutritional status of primary school children in Garhwali Himalayan villages of India. Food Nutr Bull 2010;31:221-33.
20. Kongsbak K, Wahed MA, Friis H, et al. Acute phase protein levels, T. trichiura, and maternal education are predictors of serum zinc in a crosssectional study in Bangladeshi children. J Nutr 2006;136:2262-8.

21. Roohani N, Hurrell R, Kelishadi R, et al. Zinc and its importance for human health: an integrative review. J Res Med Sci 2013;18:14457.

22. Geiser J, De Lisle RC, Andrews GK. The zinc transporter Zip5 (Slc39a5) regulates intestinal zinc excretion and protects the pancreas against toxicity. PloS ONE 2013;8:e82149.

23. Allen JE, Maizels RM. Diversity and dialogue in immunity to helminths. Nature Reviews Immunol 2011;11:375-88.

24. Zarebavani M, Dargahi D, Einollahi N, et al. Serum levels of zinc, copper, vitamin B12, folate and immunoglobulins in individuals with giardiasis. Iranian J Publ Health 2012;41:47-53.

25. Blackwell AD, Martin M, Kaplan H, et al. Antagonism between two intestinal parasites in humans: the importance of co-infection for infection risk and recovery dynamics. Proc $\mathrm{R}$ Soc B 2013;280:1671-8. 